\title{
CHARACTERISTICS OF RODENT OUTBREAKS IN THE LOW SAN FRANCISCO SERGIPANO (SERGIPE, BRAZIL) AND INFLUENCE OF ANOMALIES ON SEA SURFACE TEMPERATURE ON TEMPERATURES IN THIS REGION
}

\author{
G. CRUZ SANTOS \\ Department of Economics and Social Science \\ Polytechnic University of Valencia, Spain.
}

\begin{abstract}
Construction of the Sobradinho Dam has had a strong environmental impact on the Lower São Francisco Sergipano ("LSFS") North-East Brazil ("NEB") region. No detailed studies of the floodplain areas were conducted prior to these changes, and there are thus no records of the floristic and faunal diversity extant in this ecosystem before the dam was built. One of the worst consequences in this region has been the onset of rodent outbreaks in rice crops. The climate in NEB is highly variable, and forecasts predict high temperatures in this semi-arid region. Based on the perspective of farmers who have witnessed these environmental changes and their repercussions, the aim of the present study was to determine the specific characteristics of rodent outbreaks, the rat predators present in the region, the floral diversity in cultivated areas prior to the changes, and the influence of anomalies in sea surface temperature (SSTs) on maximum and minimum temperatures in the LSFS in the state of Sergipe between 1978 and 2010, years in which rodent outbreaks occurred.
\end{abstract}

Keywords: 'El Niño', Brazil, floodplain, Lower San Francisco Sergipano, rodent outbreaks, SOI.

\section{INTRODUCTION}

More than a third of all land mammals are rodents and they play an important role in ecosystems as propagators of seeds and spores, affecting the vegetation structure, as reported by Witmer [1]. There are about 1700 species of rodents in the world, but only 5-10\% of them are categorised as serious pests in agriculture and urban environments [2]. Since the 20th century, rodent outbreaks have aroused the interest of biologists in various parts of the world, due to their singular temporal association with the ocean-atmospheric phenomenon "El Niño" Southern Oscillation ("ENSO") [3]. Ali [4] claims that rodent outbreaks are particularly common in southeast Australia, southwest America, and semi-arid regions of sub-Saharan Africa and South America. In the Lower San Francisco Sergipano (LSFS) Valley in northeast Brazil (NEB), an area of floodplains where rice is cultivated, rice crops are periodically destroyed by plagues of rats [5-8]. The onset of crop damage by rats native to this semi-arid NEB region has been associated with the environmental changes that took place in the LSFS in 1978 as a result of the construction of the Sobradinho Dam [7,9,10], and these episodes of rodent outbreaks or "ratadas" have also been associated with ENSO events in the semi-arid regions of different South American countries [11,12]. Changes in natural and agricultural ecosystems alter the ecology of various animals, resulting in uncontrollable phenomena that affect several spheres of human life. Very little information exists on the characteristics of plagues dominated by H. sciureus (the Amazonian marsh rat), although rodent outbreaks mostly characterised by this species have been recorded in LSFS rice crops in 1978, 1982, 1983, 1988, 1993, 1998, 1999, 2005, 2009 and 2010, years also characterised by "El Niño" events [13]. The current year, 2015, has also witnessed an "El Niño" event of great magnitude $[14,15]$, and this has again coincided with rodent outbreaks 
in rice-growing areas in the LSFS basin, raising the total number of outbreaks in the region to 11 [8]. In this study, we investigated the conditions of the last recorded rodent outbreaks in the LSFS in the 20th century (1999-2000), which coincided with the "El Niño" event of greatest magnitude in that century. The objectives of this study were: (1) to identify the characteristics of rodent outbreaks in the Betume Irrigated Perimeter (BIP ("PIB")) LSFS, in terms of the most vulnerable crop growth stage, the climatic season of highest incidence, and the presence of rodent predators and/or natural enemies in the area; (2) to verify the floral diversity present in the surroundings of the study area; and (3) to analyse the influence of anomalies in Sea Surface Temperature (SST) on maximum and minimum temperatures in the LSFS between 1978 and 2010.

\subsection{Study Area and Data}

In the LSFS Valley, the BIP and Propriá are sub-regions characterised as floodplain-river-ecosystems with use of the land for rice irrigation systems. The BIP is floodplain with an average annual temperature of $25.5^{\circ} \mathrm{C}$ and a mean annual precipitation (MAP) of $1.555 \mathrm{~mm}$. The climate is sub-humid, according to Thornthwaite climate classification, with two clearly defined seasons, resulting in a wet and relatively dry and warm [16-18]. In Propriá, the climate is "megathermic", semi-arid with MAP of $806.01 \mathrm{~mm}$ and an average annual temperature of $26.1^{\circ} \mathrm{C}$ [19]. In order to determine the correlation between the ENSO events, climatic conditions of the LSFS and rodent outbreaks, we analyse the monthly maximum and minimum temperatures in the LSFS between 1978 and 2010 in a range of 10 non-sequential years in the same temporal scale in these two different geographical zones in floodplain areas which had recorded rat plagues. The same spatial and temporal scales were studied by [7]: Propriá and Betume Irrigated Perimeter ("PIB")-Neópolis in the LSFS (NEB). Their maximum and minimum temperatures (MxTp and MinTp) were compared with the respective monthly anomalies for Ocean-Atmospheric Regions (OAR) in the Equatorial Pacific Ocean for the Southern Oscillation Index SOI [20] and Niños Regions (“NR"): n1+2, n3, n4, n34 [21], and categories: North Atlantic ("NATL"), South Atlantic ("SATL"), and TROPICAL Ocean (Category Atlantic Ocean (CAO)) according to [22]. The most common correlation or predictability measurement, Pearson's correlation coefficient (r), was introduced to assess the monthly temperatures anomalies of LSFS and OAR. The significance of the relationship was expressed in the probability value $\mathrm{p}$ at a linear correlation significance level of $\mathrm{p} \leq 0.05$ and $\mathrm{p} \leq 0.01$ (*95\% and $* * 99 \%)$. The software program, SPSS, version 19.0, was used for the statistical analysis. The comparison between the temporal scale characterised by the ENSO events was checked against the National Oceanographic and Atmospheric Administration (NOAA) website [13]. LSFS monthly precipitation data were provided by INMET and CMRHSE [23] for the years 1978, 1982, 1983 and 1988 in Propriá just as [19], and by Ascondir Station in Betume-Neópolis as stated in [24] for the years 1993, 1998, 1999, 2005, 2009 and 2010. The 63 rice-growers were surveyed about the characteristics of rodent outbreaks in the region, the crop growth stage most vulnerable to the rice cycle, the climatic season of highest incidence, and the presence of rodent predators and/or natural enemies in the area. The most vulnerable crop growth stage in the rice cycle was observed in two plots in the BIP: 339 (3.8 hectares (ha)) and 341(4.9 ha). We have identified the floral diversity present in the surroundings of this study area between 1999 and -2000 and 2012; we have also analysed the influence of SSTs on MxTp and MinTp in the LSFS between 1978 and 2010. In this study, when there is a positive $r$ correlation for (SOI, NR and CAO), and LSFS 
(MxTp and MinTp), it is considered that MxTp and MinTp were increased by strong association with OAR. However, when $r$ is negative, MxTp and MinTp depend on the SSTs OAR (Independent variable $(\mathrm{X})$ ).

\section{RESULTS AND DISCUSSION}

In this study it was confirmed that, in relation to the most vulnerable crop growth stage, $33.3 \%$ of farmers considered that the growth stage presenting the highest incidence of damage was 30-60 days after sowing (tillering/stem elongation), while $17.46 \%$ responded that it was at the start of booting. Meanwhile, $7.94 \%$ respondents indicated the following stages: (a) from the 15th day after sowing; (b) between 20 and 30 days after sowing; (c) and during tillering. In the same way $6.35 \%$ responded that it was from the sowing, whereas $6.35 \%$ of the rice growers responded that it was between 60-70 days after sowing and $4.76 \%$ from the sowing until the harvest and $1.59 \%$ no answer. The sowing stage of the 1999-2000 crop in the LSFS/BIP presented significant variance in damage, with a direct loss in the fields of $40 \%$ [25]. Field studies revealed that the period of cultivation most affected by rodent outbreaks with characteristics of Holochilus sciureus was during the first 36 days after sowing, with damage to 160 seedlings in plot 339 and 110 seedlings in plot 341 . In each plot, plants were cut by rats at the following number of days after sowing: plot 339 at 36, 60 and 106 days, and plot 341 at 36 and 86 days. In Venezuela, [26] found damage to rice crops by Holochilus sciureus at 39, 53, 67, 81, 95 and 109 days after sowing. According to [27], rice crops are attacked by rats at all growth stages, but the highest occurrence is during sowing or when the panicle is starting to form, when rats cut the stalks and feed on the developing panicles. In general, rodents cause serious damage during sowing and can completely destroy the crop [28]. In rice fields in Venezuela, the damage caused by Holochilus sciureus can occur at any stage of development; however, it is greater during flowering and ripening [29], and [26] found a directly proportional relationship between the extent of damage and crop growth stage: from sowing to a maximum of 112 days, there was a higher incidence of damage in the reproductive and grain ripening stages. In Pakistan, 63.9\% of damage occurs during the rice development stages, and most damage is caused during ripening, with Mus sp. causing $1 \%$ of damage during rice development, according to Tousif [30]. In the LSFS, observations revealed that the damage occurred in all growth stages, but the highest incidence in both of the plots studied was at 36 days after sowing. In relation to the season with highest incidence of the rodent outbreaks in the LSFS in years with plague, $44.44 \%$ of farmers indicated the rainy season as the period with the highest incidence of the plague, whereas $25.40 \%$ indicated the dry season. However, $20.63 \%$ of the 63 farmers cited both periods (rainfall and drought); $6.35 \%$ no answer and $3.17 \%$ responded that rodent outbreaks is a climatic phenomenon. According to Santos $[6,10]$, rodent outbreaks in LSFS rice crops coincide with years of ENSO events, which are characterised by drought in the region. In Cañas (Guanacaste, Costa Rica), [31] identified the influence of climate variability on Sigmodon hispidus (the hispid cotton rat), whereby maximum peaks in rat population density were associated with decreased minimum temperatures in the region. Contrary to what happens in the LSFS during ENSO years, the rat population in Cañas shows a $4 \%$ decrease from usual numbers. In a study of semi-arid areas in Chile, [12] found an association between rodent outbreaks and years with wet ENSO events. As regards rodent predators in the LSFS region, the literature did not contain specific records of the genera or species that may have inhabited the floodplains used for rice cultivation prior to environmental changes in 1978. Nor is there a written record of predators that may have been occasional visitors to the rice fields. Ramos [32] stated that 


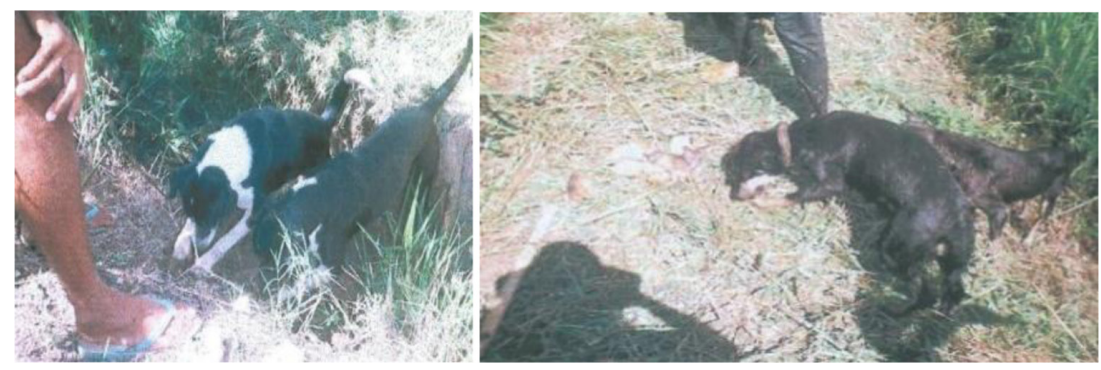

Figure 1: Dog hunters in the LSFS (1999-2000).

Environmental Impact Studies (EIS) on changes to the LSFS were incomplete, and did not consider direct and indirect effects on the floodplain ecosystem. However, $48.91 \%$ of farmers cited Canis lupus familiaris and $21.74 \%$ Felis catus as natural rat predators in the region. Canis familiaris was the only natural predator whose presence it was possible to confirm during field studies and the only reliable means for farmers to combat the rat population in the area (Fig. 1), since - as elsewhere - rat poison was not effective [33].

Snakes (order Squamata) were cited by $21.74 \%$ as predators present in rice fields before the environmental changes. Other predators reported to have formed part of the local fauna prior to the changes have now disappeared following the environmental impact on the wetland area. These included Bubo virginianus (the great-horned owl), cited by $5.43 \%$, and Elanus leucurus (the white-tailed kite), cited by $2.17 \%$. Procyon cancrivorus nigripes (the crab-eating racoon) was cited by $1.09 \%$, and lizards (suborder Lacertilia ("sardão")) by $1.09 \%$. The predators identified by farmers form part of the fauna of semi-arid regions in NEB [34]. Autochthonous rodents in the LSFS are represented by two families, Cricetidae and Cavidae $[5,7,10]$, while Muridae, which is not autochthonous, was introduced into Brazil by maritime traffic, according to Moojen [35]. Found in the LSFS were Kerodon rupestris, Oryzomys subflavus, Holochilus sciureus, Nectomys sp. and Rattus spp.; of these H. sciureus is the most prevalent species, with a predominant of damage characteristic $[5,7,10]$.

\subsection{Floral Diversity in the PIB}

The floral diversity in the study area consisted of 09 families and 15 genera. The most frequently observed families and genera were Amaranthaceae (Amaranthus sp.) (bredo, caruru); Anacardiaceae (Myracrodruon sp.) (aroeira); Boraginaceae (Cordia sp.) (erva-baleeira); Cyperaceae (Cyperus sp.) (tiririca), (Cyperus sp.) (tiriricão); Fabaceae (Aeschynomene sp.) (angiquinho), (Desmodiun sp.) (pega-pega), (Cassia o. L.) (fedegoso); Poaceae (Brachiaria sp.) (capim braquiaria), (Brachiaria sp.) (capim agulha), (Cymbopogon sp.) (capim santo), (Cenchrus sp.) (carrapicho de carneiro); Pontederiaceae (Eichhornia sp.) (jacinto d'agua); Rubiaceae (Borreria sp.) (vassourinha-de-botão); Urticaceae (Urera sp.) (urtiga vermelha). In Brejo Grande, Ilha das Flores, Neópolis, Santana do São Francisco and Propriá, other areas with floodplains in the LSFS region, Gonçalves et al. [36] found 79 species distributed among 71 genera and 51 botanic families, with a predominance of Mimosaceae (seven species), Myrtaceae (six species) and Fabaceae (four species). Observations indicate that the vegetation structure in the BIP/Betume I/Sector 8 no longer predominantly consists of naturally primitive autochthonous plant cover. Flooded areas are generally dominated by agricultural plant cover and, more specifically, by irrigated rice cultivated for the purposes of economic 
production. The effect on the vegetation structure has been to eradicate the native vegetation. The characteristic riparian woodlands located on the banks of the São Francisco River and its tributaries constitute a living memory of the flora that once formed part of these ecosystems. Subsistence farming has covered the "tabuleiros" and "cerrados" (native vegetation) in the highest areas. Drainage and irrigation have led to the loss of natural vegetation cover in favour of rice cultivation. Drainage and irrigation form the basic technological infrastructures of this new agroecosystem model.

\subsubsection{Correlation Between SSTs and Maximum (Mx) and Minimum (Min) Temperature (Tp) in the LSFS}

In Table 1, highly significant negative correlations were found in 1978 between SSTs and $\mathrm{n} 1+2 / \mathrm{MxTp}$, with high negative values for $\mathrm{r}(-0.787 * *)$, and positive values for $\mathrm{r}$ with $\mathrm{n} 3 /$ MxTp (0.715**), n3/MinTp (0.591*) and n34/MinTp (0.609*), indicating that MxTp and MinTp increased in 1978.

In 1983, strong negative correlations were observed between SOI/MxTp and MinTp $(-0.583 * ;-0.585 *)$; likewise, strong negative associations were found in 1993 between $\mathrm{n} 1+2 /$ $\operatorname{MxTp}\left(-0.700^{*}\right), \mathrm{n} 3 / \mathrm{MxTp}\left(-0.670^{*}\right)$ and n34/MxTp (-0.643*). In 1998, temperatures were reduced by correlations between SOI/MxTp $\left(-0.627^{*}\right)$ and SOI/MinTp $\left(-0.820^{* *}\right)$, with a negative $\mathrm{r}$ value, whereas minimum temperatures increased with associations between $\mathrm{n} 3 /$ $\operatorname{MinTp}\left(0.761^{* *}\right), \mathrm{n} 4 / \operatorname{MinTp}(0.672 *)$ and n34/MinTp (0.795*). In 1999, maximum and minimum temperatures/SOI showed high $\mathrm{r}$ values SOI/MxTp $\left(0.802^{* *}\right)$ and SOI/MinTp $\left(0.705^{*}\right)$ but were decreased for $\mathrm{n} 4 / \mathrm{MxTp}\left(-0.809^{* *}\right)$ and $\mathrm{n} 4 / \mathrm{MinTp}\left(-0.691^{*}\right)$, showing that the OAR produced milder temperatures through a balance (+; -) for the SOI and the n4 lake showing that the OAR produced higher temperatures through a balance $(+;-)$ for the SOI and the $n 4$ lake. From 1998 onwards, a trend was observed towards an increase in Min/Temp with strong positive correlations between lakes n3/MinTp $(0.761 * *), n 4 / \operatorname{MnTp}(0.672 *)$, and n34/MinTp $\left(0.795^{*}\right)$. In 2005 , minimum temperatures rose in association with lake $\mathrm{n} 4\left(0.620^{*}\right)$, and in

Table 1: Analysis of correlation between SSTs of OAR and temperatures in the LSFS.

\begin{tabular}{|c|c|c|c|c|c|c|c|c|c|c|}
\hline SSTs & $\begin{array}{l}\text { SOI/ } \\
\text { MxTp }\end{array}$ & $\begin{array}{l}\text { SOI/ } \\
\text { MinTp }\end{array}$ & $\begin{array}{l}\mathrm{n} 1+2 / \\
\mathrm{MxTp}\end{array}$ & $\begin{array}{l}\mathrm{n} 1+2 / \\
\mathrm{MinTp}\end{array}$ & $\begin{array}{l}\text { n3/ } \\
\text { MxTp }\end{array}$ & $\begin{array}{l}\text { n3/ } \\
\text { MinTp }\end{array}$ & $\begin{array}{l}\text { n4/ } \\
\text { MxTp }\end{array}$ & $\begin{array}{l}\text { n4/ } \\
\text { MinTp }\end{array}$ & $\begin{array}{l}\text { n34/ } \\
\text { MxTp }\end{array}$ & $\begin{array}{l}\text { n34/ } \\
\text { MinTp }\end{array}$ \\
\hline 1978 & -0.561 & -0.051 & $\begin{array}{l}-0,787 \\
* *\end{array}$ & 0.453 & $0.715 * *$ & $0.591 *$ & 0.293 & 0.543 & 0.430 & $0.609 *$ \\
\hline 1982 & -0.088 & 0.300 & 0.335 & 0.020 & 0.358 & 0.021 & 0.086 & 0.263 & 0.320 & -0.030 \\
\hline 1983 & $-0.583 *$ & $-0.585 *$ & -0.561 & -0.462 & 0.025 & 0.162 & 0.102 & 0.240 & 0.221 & 0.386 \\
\hline 1988 & 0.103 & 0.031 & 0.540 & 0.306 & 0.237 & 0.237 & 0.286 & -0.118 & 0.420 & 0.021 \\
\hline 1993 & 0.223 & 0.330 & $-0,700 *$ & -0.339 & $-0.670 *$ & -0.189 & 0.452 & 0.201 & $-0.643 *$ & -0.031 \\
\hline 1998 & $-0.627 *$ & $-0.820 *$ & 0.165 & 0.541 & 0.425 & $0.761 *$ & $=0.311$ & $0.672 *$ & 0.433 & $0.795^{*}$ \\
\hline 1999 & $\begin{array}{c}0.802 \\
* *\end{array}$ & $0.705^{*}$ & 0.415 & 0.237 & 0.010 & -0.308 & $\begin{array}{c}-0.809 \\
* *\end{array}$ & $\begin{array}{c}-0.691 \\
*\end{array}$ & -0.124 & -0.328 \\
\hline 2005 & -0.274 & -0.471 & -0.271 & -0.005 & -0.282 & 0.153 & 0.446 & $0.620 *$ & -0.125 & 0.168 \\
\hline 2009 & -0.473 & 0.270 & 0.281 & $0.652 *$ & $0.800 * *$ & ${ }^{*}-0.486$ & $0.869 * *$ & -0.407 & $0.868 * *$ & -0.380 \\
\hline 2010 & 0.193 & -0.203 & -0.497 & 0.068 & -0.310 & 0.178 & -0.398 & 0.156 & -0.312 & 0.222 \\
\hline
\end{tabular}

$* 90 \% * * 99 \%$. 


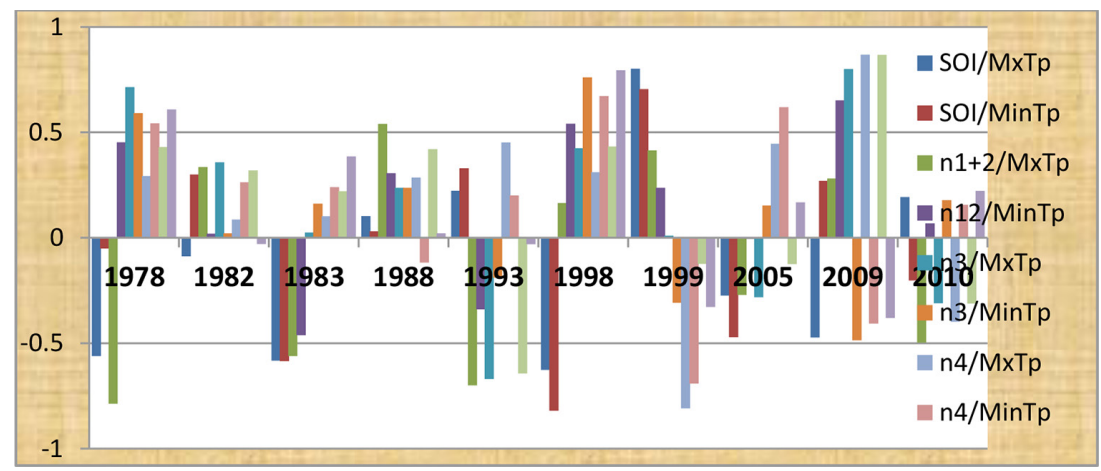

Figure 2: Graphic representation correlation (Table 1).

2009, minimum temperatures were increased with positive values for lake $\mathrm{n} 1+2(0.652)$, and maximum temperatures for $\mathrm{n} 3$ (0.800), $\mathrm{n} 4$ (0.869), and n34 (0.868). The years 1982, 1988 and 2010 were characterised by the absence of significant correlations between SSTs "Niños Regions" and temperatures in the LSFS (see graphic representation in Fig. 2).

As regards the Atlantic categories and the associations between SSTs and maximum and minimum temperatures in the LSFS, as shown in Table 2, in 1978 the Tropical Atlantic induced a rise in minimum temperatures with a strong and positive $\mathrm{r}$ value $\left(0.608^{*}\right)$; the same thing occurred in the SATL category in 1982 , with a positive $\mathrm{r}$ value $\left(0.757^{* *}\right)$. In 1983 , maximum and minimum temperatures tended to increase the very significant positive $\mathrm{r}$ correlations with $\left(0.807 * * ; 0.680^{*}\right)$. In 1993 , a positive $\mathrm{r}$ value $\left(0.720^{* *}\right)$ indicated SSTs in NATL contributed to an increase in maximum temperatures that year. In 1998, strong positive associations were observed between SATL/MinTp (0.501*) and TROPICAL/MnTp (0.629*), and in 1999, MxTp and MinTp maintained a balance with strong positive-negative correlations for the MxTp/MinTp SATL category (0.682*; $\left.-0.722^{* *}\right)$.

Table 2: Analysis of correlation between SSTs of CAO (NATL/SATL/TROPICAL) and temperatures in the LSFS.

SSTs/Years NATL/MxTpNATL/MinT SATL/MxTpSATL/MinTpTrop/MxTp Trop/MinT

\begin{tabular}{lccllll}
\hline 1978 & 0.275 & 0.048 & -0.076 & 0.125 & 0.483 & $0.608^{*}$ \\
1982 & -0.423 & -0.064 & 0.425 & $0.757 * *$ & 0.213 & 0.059 \\
1983 & 0.301 & 0.089 & $0.807^{* *}$ & $0.680^{*}$ & 0.071 & 0.152 \\
1988 & -0.294 & -0.479 & -0.395 & -0.347 & 0.357 & 0.068 \\
1993 & 0.720 & 0.112 & 0.407 & -0.079 & -0.342 & -0.077 \\
1998 & -0.549 & -0.402 & -0.023 & $0.501^{*}$ & 0.240 & $0.629 *$ \\
1999 & -0.411 & -0.369 & $0.682^{* *}$ & $-0.722^{* *}$ & 0.027 & -0.206 \\
2005 & -0.035 & 0.410 & $0.756^{* *}$ & $0.606^{*}$ & 0.367 & $0.751^{*}$ \\
2009 & $0.750^{* *}$ & -0.347 & -0.364 & $0.631^{*}$ & $0.789^{* *}$ & -0.525 \\
2010 & -0.395 & -0.471 & -0.395 & -0.021 & -0.386 & -0.001 \\
\hline
\end{tabular}

$* 90 \% * * 99 \%$ 
In the last decade in the LSFS, in 2005, MxTp and MinTp were influenced by the activities of the SSTs of the SATL, with $r$ positive $\left(0.756^{* *} ; 0.606^{*}\right)$ and the TROPICAL, with a strong positive $r$ for TROPICAL/MinTp (0.751). In 2009, the NATL and the TROPICAL caused an increase in maximum temperatures $\left(0.750^{* *} ; 0.789^{* *}\right)$, with strong positive values for $\mathrm{r}$, and the SATL/MinTp with $\mathrm{r}\left(0.631^{*}\right)$, in like manner increasing minimum temperatures. In 1988 and 2010, in the Category: Atlantic Ocean NATL, SATL and TROPICAL -as with the OAR, the "El Niño" lakes and SOI- no significant correlations were observed between SSTs and temperature conditions in the LSFS. In the period studied, a trend was observed in "Niño lakes" n3 and n34 in 1978, in n3, n4 and n34 in 1998, and in n1+2 in 2009, raising minimum temperatures; meanwhile, n3 in 1978, n4 in 1999, and n3, n4 and n34 in 2009, showed a rise in maximum temperatures. The SSTs/SOI contributed with a decreased to MxTp and MinTp in 1983 and in 1998 and an increase in MxTp and MinTp in 1999. Atlantic categories maintained strong association with maximum and minimum temperatures in the LSFS with strong positive $r$ value for the years $(78,82,83,93,99,2005,09)$, and with an increase in positive values in 2005 and 2009 in the last decade (see graphic representation in Fig. 3).

It can be inferred that in years characterised by an "El Niño" event, there is a tendency for maximum and minimum temperatures in the LSFS to rise. According to [7], the period 19782010 was largely characterised by years of drought or low rainfall in the LSFS and by ENSO events. Forecasts for the climate in NEB until the end of the present century predict a 15-20\% reduction in rainfall and a $2^{\circ} \mathrm{C}$ to $4^{\circ} \mathrm{C}$ increase in temperatures. Semi-arid areas with a greater water deficit are expected to suffer an increase of $3^{\circ} \mathrm{C}$ or more in average temperatures, and there is a greater possibility of drought in the semi-arid region of NEB [37]. Studies of summer seasons in Paraíba (NEB) between the years 1963 and 1999, inclusive, indicated an increase in maximum temperatures in almost all the micro-regions in this province, except in the "Agreste" zone [37]. The BIP was a floodplain and it is characterised as a "Agreste" zone in Sergipe; meanwhile, Propriá is a semi-arid micro-region. Rice fields serve as a habitat for wild species and other animals, and rivers and floodplains as systems which cannot be separated $[38,39]$.

According to farmers, the crop growth stage most vulnerable to rodent damage was identified as being between 30-60 days after sowing, while the rainfall period was identified as the climatic season showing the highest incidence of rodent outbreaks, contrary to our observations. The Canis familiaris was the only natural predator whose presence it was possible to

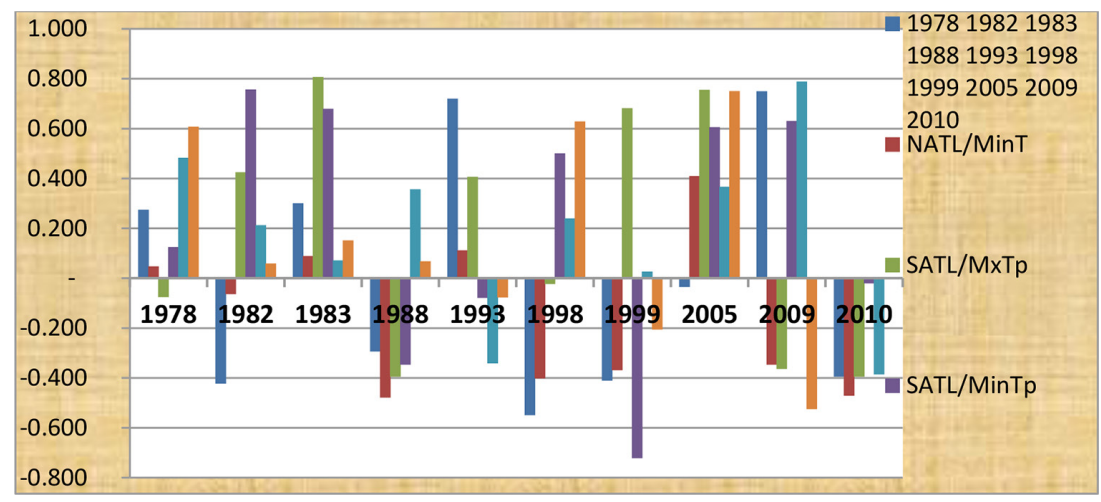

Figure 3: Graphic representation correlation (Table 2). 
confirm during the field study, and nowadays it is the only reliable means for farmers to combat the rat population in the area. The most frequently observed families among the floral diversity in the IBP were: Fabaceae and Poaceae. This study identifies a much larger influence of SSTs on temperature in the LSFS related to the association with SOI, n4 lake and the SATL Ocean. Finally, in the period studied between 1978-2010, a trend was observed: there is an equilibrium between correlations of SSTs SOI and "Niños Regions" in relation to maximum and minimum temperatures in the LSFS; meanwhile, in the SSTs of CAO there is a trend towards an increase in the association with the maximum and minimum temperatures in the LSFS, with strong positive correlation.

\section{REFERENCES}

[1] Witmer, G.W., Rodent ecology and plague in North America. Proceedings of the 1 gth International Congress of Zoology. China Zoological Society, Beijing, China, pp. 154-156, 2004.

[2] Stenseth, N.C., Leirs, H., Skonhoft, A., Davis, S.A., Pech, R.P., Andreassen, H.P., Singleton, G.R., Lima, M., Machang'u, R.S., Makundi, R.H., Zhang, Z., Brown, P.R., Shi, D. \& Wan, X., Mice and rats: the dynamics and bioeconomics of agricultural rodents pests. Frontiers in Ecology Environment, 1(7), pp. 367-375, 2003.

https://doi.org/10.1890/1540-9295(2003)001[0367:mraptb]2.0.co;2

[3] Aceituno, P., El Niño, the Southern Oscillation, and ENSO: confusing names for a complex ocean-atmosphere interaction. Bulletin of the American Meteorological Society, 73, pp. 483-485, 1992.

https://doi.org/10.1175/1520-0477-73.4.483

[4] Belmain, S.R., Ali, M.S., Azad, A.K, Chakma, L.C., Dewan, U., Harun, M., Hasanuzzaman, A.T.M., Islam, S.M.F., Kadry, M.N.I, Kamal, N.Q., Sarker, N.J., Sarker, S.K. \& Sarker, S.U., Bamboo Flowering, Rodent Outbreaks and Food Security: Rodent Ecology, Pest Management, and Socio-economic Impact in the Chittagong, Hill Tracts. United Nations Development Programme, Bangladesh, 2008.

[5] Sergipe, Servicio de vigilância sanitária regional de. Projeto para controle de roedores no Estado de Sergipe, 1995.

[6] Santos, G.C., Variación y proporción de varianza de (ROA) regiones océano atmosféricas y $(\mathrm{AH})$ áreas húmedas en años ENOS con o sin ocurrencia de "ratadas", el caso del (BSFS) Bajo San Francisco Sergipano, (NEB) Nordeste de Brasil. Revista Digital de Medio Ambiente "Ojeando la Agenda", 24, July, 2013.

[7] Santos, G.C., Environmental changes and temporal distribution of order Rodentia in North-East Brazil (NEB), and its link to the El Niño Southern Oscillation (ENSO) and drought in the region. Ecosystems and Sustainable development, WIT Transactions on Ecology and The Environment, 192, pp. 33-41, 2015.

[8] Ratos ameaçam produção de arroz em SE, available at http://destaquesdoserido. blogspot.com.es/2015/05/ratos-ameacam-producao-de-arroz-em-se.html (accessed 30 May 2015)

[9] Barros, H.O., Monteiro de. Modernização agrícola autoritária e desestruturação do ecosistema: o caso do Baixo São Francisco. Cad. Est. Soc., Recife, 1(1), pp. 97-113, 1985.

[10] Santos, G.C., Relação sociedade-natureza e a problemática da infestação de roedores (ratos) em área irrigada cultivada com arroz (Oriza sativa L.) no baixo São Francisco sergipano. Master. Dissertation, Núcleos de Estudos do Semi-Arido-NESA, Universidade Federal de Sergipe: Aracaju, pp. 175, 2000. 
[11] Jaksic, F.M., The multiple facets of El Niño/Southern Oscillation in Chile. Revista Chilena de Historia Natural, 71, pp. 121-131, 1998.

[12] Lima, M., Marquet, P.A. \& Jaksic, F.M., El niño events, precipitation aprrens, and rodent outbreak are statistically associated in semi-arid Chile. Ecography, 22, pp. 213 218, 1999. https://doi.org/10.1111/j.1600-0587.1999.tb00470.x

[13] NOAA, available at http://ggweather.com/enso/oni.htm (accessed 30 May 2015).

[14] NOAA, available at http://www.cpc.ncep.noaa.gov/products/analysis_monitoring/ ensostuff/ensoyears.shtml (accessed 30 May 2015).

[15] FranceTVinfo, available at http://geopolis.francetvinfo.fr/el-nino-une-perturbationclimatique-de-grande-intensite-annoncee-pour-cet-hiver-80897 (accessed September 2015).

[16] Estado de Sergipe/Serviço de Extensão Rural/ANCARSE. Plano de ação para os vales úmidos do Baixo São Francisco. SUVALE/ANCARSE, Aracaju, 1972.

[17] Codevasf. Relatório de comissão construída através da determinação 001/83 da $4^{\text {a }} D R$, para avaliação de lotes do Projeto Betume Sequeiro: Aracaju, Fev, 1983.

[18] Codevasf. Ficha técnica do Perímetro Irrigado Betume, 1999, Aracaju: SEPRE/ CODEVASF. $4^{\text {a }}$ Superitendência Regional, pp. 11, 1999.

[19] Bomfim, Luis F.C., Costa, I.V.G. da, \& Benvenuti, Sara M.P., Diagnóstico do municipio de Propriá. Projeto cadastro da infra-estructura hídrica do Nordeste- Estado de Sergipe: Aracaju, 2002.

[20] NOAA, available at http://www.cpc.ncep.noaa.gov/data/indices/soi (accessed September 2015).

[21] NOAA, available at http://www.cpc.ncep.noaa.gov/data/indices/ersst3b.nino.mth.ascii (accessed September 2015).

[22] NOAA, available at http://www.cpc.ncep.noaa.gov/data/indices/sstoi.atl.indices (accessed September 2015).

[23] INMET-CMRHSE, available at http://www.agritempo.gov.br/agroclima/sumario? uf=SE (accessed September 2015).

[24] ASCONDIR-Estación Meteorológica: Platô de Neópolis. Dados climáticos mensuales: 1998, 1999, 2005, 2009, 2010.

[25] Santos, G.C., Variación de daños provocados por ratas en arrozales del Bajo San Francisco Sergipano (BSFS). Revista Digital de Medio Ambiente "Ojeando la Agenda", 23, May, 2013.

[26] Ramón, L.M.F., Comportamiento poblacional de la rata arrocera Holochilus sciureus (Rodentia: Cricetidae) en una unidad de producción de arroz del Estado Portuguesa. Tesis Doctoral. Universidad Central de Venezuela, Maracay, 2012.

[27] Cheaney, R.L.Y. \& Jennings, P.R., Problemas en cultivo de arroz en América Latina. Colombia, CIAT, 1975.

[28] Ordoñez, Y.J.C., Evaluación de características agronómicas de cuatro líneas interespecificas de arroz (Oriza Sativa/Oriza Latifolia) comparadas con dos variedades comerciales y una específica en el corregimiento \#8 de Zacarías municipio de Buenaventura. Universidad del Pacífico Facultad de Ciencais Naturales y Exactas, 2008.

[29] Poleo, J.C. \& Mendonza, J.R., Actividad reproductiva de la rata arrocera (Holochilus sciureus) en siembras de arroz del sistema de riego río Guárico, Clabozo, Estado Guárico. Fundación para la Investigación Agrícola DANAC, 2004. 
[30] Tousif, S.B., Feeding patterns of rodents damaging rice and wheate fields in Sindh Pakistan (Doctoral Dissertation). Philosophy in zoology Deptartment, Zoology University, Karachi, 2006.

[31] Retana, J., Solera, M. \& Solano, J., Efecto de la variabilidad climática sobre la Fluctuación poblacional de la rata cañera (Sgmond hispidus) en cañas, Guanacaste. Taboga: Instituto Meteorologico Nacional Gestion de Desarrollo Hernández Alvarez Ingenio Taboga Manejo de Plagas, pp. 11, 2000.

[32] Ramos, V.O.C., Pesca Pescadores e políticas públicas no Baixo São Francisco SergipeBrasil. Tesis de Maestría publicada. Núcleos de Estudos do Semi-Arido-NESA, University, Federal de Sergipe: Aracaju, 1999.

[33] Eiris, G.C. \& Barreto, G.R., Home range of marsh rats, Holochilus sciureus, a rodent pest in rice fields of Venezuela. Inter. INCI, 34(6), Caracas jun, 2009.versión imprensa ISSN 0378-1844.

[34] Paiva, P.M. \& Campos, E., Fauna do nordeste do Brasil conhecimento popular. Banco do Nordeste do Brasil: Fortaleza, 1995.

[35] Moojen, J., Os roedores do Brasil. Rio de Janeiro, 1952.

[36] Gonçalves, F.B., Santos, L.G.da C., Ribeiro, L.F., Araújo-Filho, R.N., et al. Levantamento florístico realizado na margen direita do Baixo curso do rio São Francisco no Estado de Sergipe, Brasil. Sociedade de Ecologia do Brasil, VIII CEB, Anais do VIII Congresso de Ecologia do Brasil, Caxambu, MG- 23 a 28 de Setembro de 2007.

[37] Marengo, J.A., Impactos das mudanças climáticas no bioma caatinga e na desertificação do semi-árido. Ministério de Ciência e Tecnologia, Instituto Nacional de Pesquisas Espaciais, ca.2008.

[38] Tadeo, A.J.P., Martinez, E.R. \& Estruch, V., Farming efficiency and the survival of valuable agro-ecosystems: a case study of rice farming in European Mediterranean Wetlands. Open Environmental Sciences, 3, pp. 42-51, 2009. https://doi.org/10.2174/1876325100903010042

[39] Junk, W.J. \& Wantzen, K.M., The flood pulse concept: new aspects, approaches and applications-an update. In R.L. Welcomme \& T. Petr (Eds.), Proceedings of the second international symposium on the management of large rivers for fisheries. FAO Regional Office for Asia and the Pacific, Bangkok, pp. 117-149, 2004. 